\title{
Charles Brockden Brown's Wieland or, Fiction as an Instrument of Salvation in Post-Revolutionary America
}

Carme Manuel Manuel

Universitat de València

\begin{abstract}
When in 1798 Brown finished writing Wieland or, the Transformation, an American Tale, he sent a copy of the book to Thomas Jefferson, who was then Vice President of the United States. The fact that Brown intended his text to be read for the first time by such an outstanding figure of the nation shows that he had written the novel with a clear aim in mind. Retaking Jane Tompkins's reading of the novel as a work useful in the area of national politics, I will discuss that this text is firmly rooted in the historical background of post-Revolutionary America and that as such, it is a desperate warning note on the dangers lurking within the optimistic dream of a new society. From this point of view, I read Wieland neither as an expression of Brown's preoccupation with art and artifice, nor as a symbolic representation of the universal dark side of human consciousness, nor as a battle between Calvinist pessimism and the merits of Enlightenment idealism. Neither do I read it as a political tract, but as a post-revolutionary jeremiad which encapsulates a passionate analysis on some aspects of eighteenth-century American thought and culture. Consequently, the two different sets of components - Gothic elements and explorations of social, political and philosophical questions - are made to serve one main objective: the dissection of the American mission and of the happy assurances of national selffulfillment endorsed by the Republican ideology.
\end{abstract}

Charles Brockden Brown was the first American writer of fiction "to use melodrama significantly and he was thus a genuine precursor of the later romance-novelists", manifested Richard Chase in his classic The American Novel and Its Tradition. Yet, according to an article published in July 1824 in The North American Review, Brown had not "produced an American novel. So far from exhibiting any thing of our native character and manners, his agents are not beings of this world: but those dark monsters of the imagination, which the will of the master may conjure up with an equal horror in the 
shadows of an American forest, or amidst the gloom of long galleries and vaulted aisles. His works have nothing American but American topography about them". The essay then elaborated its idea of the mission of the American novel, which was to present "fac similies of the peculiarities of the country, and consist in strong graphic delineations of its bold and beautiful scenery, and of its men and manners, as they really exist" (quoted in Baym, 1987: 225, 244).

Yet, when in 1798 Brown finished writing Wieland or, the Transformation, an American Tale, he sent a copy of the book to Thomas Jefferson, who was then Vice President of the United States. The fact that Brown intended his text to be read for the first time by such an outstanding figure of the nation shows that he had written the novel with a clear aim in mind. He had a target audience that far from abstract focused on a specific type of reader - a politician, a man of state. Retaking Jane Tompkins's reading of the novel as a work useful in "the area of national politics", as "an attempt to influence public policy", I will discuss that this work is firmly rooted in the historical background of postRevolutionary America and that as such, it is a desperate warning note on the dangers lurking within the optimistic dream of a new society. From this point of view, I read Wieland neither as an expression of Brown's preoccupation with art and artifice, nor as a symbolic representation of the universal dark side of human consciousness, nor as a battle between Calvinist pessimism and the merits of Enlightenment idealism ${ }^{1}$. Neither do I read it as a political tract (Tompkins, 1985: 44), but as a post-revolutionary jeremiad which encapsulates a passionate analysis on some aspects of eighteenth-century American thought and culture. Consequently, the two different sets of components - Gothic elements and explorations of social, political and philosophical questions-- are made to serve one main objective: the dissection of the American mission and of the happy assurances of national self-fulfillment endorsed by the Republican ideology.

In the "Advertisement" which prefaces the novel, we read that its author aims at "the illustration of some important branches of the moral constitution of man"2. Tompkins says that the novel is directed toward "solving the problems of post-Revolutionary society" and that it "presents a shocking and uncharacteristically negative view of what it meant to survive the War of Independence" (1985: 44). Brown did not share Thomas Paine's and Thomas Jefferson's enthusiasm towards the glories of independence, but was decply concerned not only, as Tompkins states, with warning people of "its horrifying consequences", but with a profound disquiet towards the loss of the true role of America, with the desperate awareness that corruption burrowed behind the sanguine proclamations of liberty and equality.

Sacvan Bercovitch defines the American jeremiad as "a ritual designed to join social criticism to spiritual renewal, public to private identity, the shifting 'signs of the times' to certain traditional metaphors, themes, and symbols" (1978: xi). The Revolutionary War had contributed toward broadening the scope of the jeremiad. The mobilization the Protestant patriots implied an intimate fusion of the religious with the political in a wholly secular sense. "If the Puritans Jeremiahs had justified the errand by reference to the Israelite exodus, the eighteenth-century Jeremiahs justified both the Israelite exodus and the Puritans by reference to their own progress". Yet, as soon as peace was declared jeremiads resumed their lament. The confrontation had not solved the crisis, and as the 
pre-revolutionary Jeremiahs, ministers saw "evidence wherever they looked of degeneracy -'delicacies and luxuries' abounding, 'unsubdued lusts permitted to range and riot at large among the tempting sweets of a fertile peaceful country' - an ungrateful people that gave every sign of seeking a captain to lead them back to Egypt. The thunder of their moral complaint against popery, corruption, and backsliding, self-love and self-interest, 'dissipation, extravagance, gaming, idleness and intemperance' continued into the Revolutionary era". Bercovitch underscores the malleability of the jeremiad and its widespread and effective use to mobilize the country in the period to such a degree that "never did the voice of Jeremiah sound more loudly in the land than in the springtime of the republic". Danger as saving providence, disaster leading to renewal were strategies of the colonial jeremiad". Thus, if "the jeremiad played a central role in the war of independence", "the war in turn confirmed the jeremiad as a national ritual (1978: 117 119,132 ).

On the other hand, in 1790s literary discourse was used as a vehicle for political claims. National politics, in the Revolutionary and post-Revolutionary decades, was the dominant theme of American writing. Bercovitch explains how "the overthrow of imperial power set loose a libertarian spirit that terrified moderate and propertied democrats. Their terror is evident everywhere in the literature: in nervous satires of an egalitarian worldturned-upside-down; in Gothic novels and tales of violated taboos (parricide, incest, idolatry); and most explicitly, in the Federalist jeremiads, warning against unbridled ambition and denouncing a long series of local insurrections, from the Whiskey Rebellion to the Antirent War" (1978: 134). Yet, it is necessary to remember, as Robert Bain observes, that "though Federalists and Antifederalists disagreed on many points, they also shared common assumptions". In 1787 most American political thinkers agreed that the Articles needed revising to prevent a crisis, that some form of union was necessary for the states, that a republican government best suited the aspirations of American society, that government should rest on the consent of the people, that government power should be limited, that men may be capable of reason but are more often ruled by their passions, and that power can corrupt $(1977: 258)$. The motif of these Federalist Jeremiahs is transparent in the momentous choice they posed, "on one side, apocalyptic disaster; on the other side, millennial glory earned through a process of taming, binding, curbing, restraint. Like their predecessors, they were berating the present generation for deviating from the past in order to prod it forward toward their vision of the future. In ritual terms, they were asserting consensus through anxiety, using promise and threat alike to inspire (or enforce) generational rededication" (Bercovitch, 1978: 135-136).

Set against this historical background, Brown's novel emerges not only a "shaper of public morality" (Tompkins, 1985: 45), but as a "cautionary tale", a warning lament framed following the cast of the jeremiad which became a ritual particularly suited to the troubled mood of post-Revolutionary America. Brown's threnody, like the Federalists', expresses the dangers inherent in social, technological, and economic growth; and like the Jeremiahs of old, he also supports "the system by calling attention to its current dysfunctions" (Bercovitch, 1978: 137). Yet, while the patriots used the jeremiad as a ritual of exorcism of foreign demons to redirect the American Israel to its mission, Brown shows that these demons are inside the actors of the new sacred drama and cannot be disposed 
of so easily. Thus, he turns the familiar jeremiad as a form capable of channelling messianic impulses into a lesson for national literary genealogy. To dramatize how the Republican dream was built on the brink of the abyss, he sets himself the task of dissecting the social ideal of the Republic and its typology of America's mission. Before the Revolution expectations were created around the great changes independence would accomplish. Vice, corruption, degeneration would dissapear from this chosen land. But Brown demonstrates in Wieland that the Lockean dream of tabula rasa is a utopian fabrication and carefully depicts America as a dystopia. To do so his narrative revolves around two main points. Firstly, the idea that separation from the Old World is unattainable. This precludes a referential movement into the past that lingers on the characters' lives affecting their decisions and actions. And, secondly, an emphasis on fiction writing - which involves a transformation of the Word- as the only possibility to recompose external reality and personal identity.

Clara Wieland, the narrator of the novel, initiates her tale tracing back the history of her family in Europe and that of her father's ancestry. An attempt to disentangle the present implies necessarily a return to the beginning that highlights the extent to which the American myth took root in the past. Wieland's grandfather is born a noble, receives a gentleman's education that pays special attention to the arts and literature. Yet, his marriage to the daughter of a merchant results in rejection and familial ostracism. This obliges him to live on what previously was merely a source of amusement and he becomes the founder of the German Theatre. Unfortunately, he and his wife die young and their only child becomes the apprentice of a London trader until one day he chances to light upon a religious book which spurs his conversion to evangelical Protestantism. Imbibed with the opinion that it is "his duty to disseminate the truths of the gospel among the unbelieving nations" (16), he decides to emigrate to America to convert the Indians. Wieland's father becomes thus the embodiment of the Puritan mission -the performer of the errand into the wilderness--, setting the pace of the first of the "transformations" that will threaten and utimately destroy the fantasy of an idyllic reality.

But the impression that this motif of exhibiting past history is used as anecdotic and explanatory background for the development of the present story is soon counteracted by the way Clara sets the oncoming events. The pro-Revolutionary writers and thinkers pointed out that in fleeing the Old World, the emigrants were abandoning a decayed monarchical order to establish a new way of life, civic and economic as well as religious, and it was to their cause of liberty, rather than to some Old World despot, that filial allegiance was due. According to Gordon S. Wood, "increasingly during the 1760 s and the early 1770 s, patriot leaders drew on the image of a 'chosen band, removed from the depravation of [...] Europe', going forth to receive 'the heathen [...] for an inheritance and these uttermost parts of the earth [for] a possession'. Increasingly, they invoked what they construed to be the libertarian legacy of the Puritan founders. And increasingly, they spoke of the emerging conflict for independence in apocalyptic terms" (quoted in Bercovitch, 1978: 121). But in Wieland physical separation --masking the political Revolution-only brings about temporal improvement as behind the Puritan fulfillment of God's plan in the New World there is not only a breach of social order but a shatterring of individual identity. If in the post-revolutionary jeremiads independence, as an act of filiopietism, was 
"America's long-prepared-for, reverently ordered passage into national maturity" (Bercovitch, 1978: 123), Wieland attests to the contrary. National maturity together with personal initiation into experience are only apparent and superficial becoming, as in Wieland's father, "offences incapable of expiation" (20).

On the other hand, Brown also dispels the dream of succession of the messianic compromise. The Whig leaders used the jeremiad to turn it into an instruction for the birth of the nation. This lesson led to what Bercovitch calls "the familiar figural imperative: what the fathers began, the sons were bound to complete" (1978: 123). Wieland's son, Theodore, rightly finishes part of his father's task of transformation, but ironically this ends up not in triumphant retrieval of a virtuous paternal heritage but in the awful resurrection of his deadly anxieties. Wieland, the embodiment of the new American, turns out to be far from the ideal transplanted European Crèvecoeur's describes in his Letters from an American Farmer. The myth of America as a land of regeneration belies man's opportunity to escape from the blemishes of a corrupt Old World. As in Crèvecouer's text, here are concepts such as "metamorphosis" and "resurrection", but emptied of all sense of millenial candour. As the subtitle manifests, "transformation" casts then a double image. Fathers pass on a suspicious inheritance that blights their children's happiness and virtue both in the religious and republican sense. It is true that at the beginning of the novel, Theodore and Clara lead different lives from their father. Instead of mad Calvinism, they follow the precepts of the Enlightenment. The temple built by their fanatic progenitor to his fearsome god has been converted/transfomed into a retreat for leisure. But this is a place born out of madness and irrationality and it is doomed to cloak those same tendencies that once produced it. Insanity cracks the place and through the dark crevice the sins of the father, in the form of Carwin, will visit his children. Not only this, but even Mettingen - the place where Clara and Theodore live- echoes German culture and civilization. In fact, what at first is described as an idyllic self-contained paradise is later presented as being situated next to the threatening environment of a nearby swamp:

The shore is deformed with mud and encumbered with a forest of reeds. The fields, in most seasons, are mire; but, when they afford a firm footing, the ditches by which they are bounded and intersected are mantled with stagnating green, and emit the most noxious exhalations [...] The scenes which environed our dwellings at Mettingen constituted the reverse of this. Schuylkill was here a pure and translucid current broken into wild and cealess music by roy points (58).

Contrary to the dictums heralded by the Englightenment thinkers who connected religion and patriotism and represented the cause of America as the cause of Heaven affirming the same typology of mission, Brown casts a shadow upon the Revolutionary certainty that Republican America has been cleansed of European depravity. In that sense, Wieland is framed following the pattern of the jeremiad described by Gordon S. Wood as a "form that guaranteed millennial frenzy out of the very process of self-doubt" (quoted in Bercovitch, 1978: 121). In fact, in what may be considered an ironical turn of the plot, Theodore - sporting an environmentalist Rousseaunian philosophy - rejects his land inheritance in Germany and his move into "a land of turbulence and war" (49), since a 
change of place and condition would possibly transform him into "a tyrant and voluptuary" (48). For Wieland believes that "no spot on the globe enjoyed equal security and liberty to that which he at present inhabited" (48).

But Wieland is not only an analysis of the ideal set against the actual. The utopian dream of democracy as an alternative to the old social ideal is undermined in the novel by a fragmented approach to what is perceived as reality. Carwin, the originator and manipulator of voices, brings about chaos and destruction because the seeds of that same destruction are not planted anywhere but in the characters's morality. Brown uses a rhetoric of trial which provides support for his emphasis on the inherited imperfection of human nature. Thus the smallest test on the shaky foundations the American Republican ideal is more than enough to make it crumble to pieces. At the end of the novel, Clara boldly asserts that

the evils of which Carwin and Maxwell were the authors owed their existence to the errors of the sufferers. All efforts would have been ineffectual to subvert the happiness or shorten the existence of the Stuarts, if their own frailty had not seconded these efforts. If the lady had crushed her disastrous passion in the bud, and driven the seducer from her presence when the tendency of his artifices was seen; if Stuart had not admitted the spirit of absurd revenge, we should not have had to deplore this catastrophe. If Wieland had framed juster notions of moral duty and of the divine attributes, or if I had been gifted with ordinary equanimity or foresight, the double-tongued deceiver would have been baffled and repelled (275-276).

All the utopian dreams of the founders of the Republic are mere chimeras when confronted with experience. In 1778 Dr. Benjamin Rush had declared that "Virtue, Virtue alone [...] is the basis of a Republic". Though the meaning of the term was much debated in the last quarter of the eighteenth century, it seems that from about 1776 onward, it came to be associated with the term republicanism to indicate "specific moral goals embedded in a code of nationhood holding that government should be based solely on the consent of the governed" and, consequently, a successful American Republic would "harbor citizens willing to give up their own private interests for the good of the whole", and this republic would best be secured in the virtue of its citizens (Mulford, 1996: xiv). But Wieland casts ominous doubts on the ideal of a virtuous citizenry and, while it proposes a study of the process of knowledge, it puts both the empirical epistomology of Locke and the goodness of religious revelation to examination. Republican citizens described in the novel are at a loss in a world where their senses are a continous source of misapprehensions. Clara Wieland's anxieties show that the making of a virtuous citizen is not just a question of curbing the environmental influences or educational background. The past becomes the shaper of morality and as such an impossible burden to overthrow.

Yet, reality is only fashioned in the novel as a language construct and hence, Wieland does not attack fiction as a corrupted mode of entertainment. Reading fiction is not intrinsically evil. What Brown discusses and questions is the perception of the reader, the misleading faculty of sensorial approach to reality that depends directly on the morality 
of the perceiver. Brown in fact sees through the natural moral self his contemporary culture celebrated and displays it in its full ambiguity.

In the letter he sent Jefferson together with a copy of Wieland, he defended his book against the traditional charge of the time that novels were frivolous time-wasters and corruptors of the youth, arguing that "fictitious narratives through an artful display of incidents [...] the powerful delineation of characters and the train of eloquent and judicious reasoning" deserve as much respect as "social and intellectual theories, and the history of facts in the processes of nature and the operations of government" (Tompkins, 1985; 46). In the preface of his first and unpublished novel, Sky Walk; or The Man Unknown to Himself, Brown had already presented his polemic on the moral legitimacy of fiction writing and novel reading. He claimed that "the nation's leaders were the ones who most needed to read fiction because the best novels most effectively portray the realities of the human condition", and he distinguished between those who simply appealed to popular taste and his own serious more intellectually demanding works:

The popular tales have their merit, but there is one thing in which they are deficient. They are generally adapted to one class of readers only [...] [and] are spurned at by those who are satisfied with nothing but strains of lofty eloquence, the exhibition of powerful motives, and a sort of audaciousness of character. The world is governed not by the simpleton but by the man of soaring passions and intellectual energy. By the display of such only can we hope to enchain the attention and ravish the souls of those who study and reflect (quoted in Elliot, 1994: ix).

In November, 1794, Brown wrote to William Dunlap: "It used to be a favorite maxim with me, that the genius of a poet should be sacred to the glory of his country [...] National songs, strains which have a peculiar relation to the political or religious transactions of the poet's country, seem to be the most precious morsels" (quoted in Pattee, 1926: xvi). Brown's reviews suggest that for the author the novel was the most effective of the literary forms: "The selection of a theme truly important, adoming it with the lustre of eloquence, supplying, with judicious hand, the deficiencies of history, in the statements of motives and the enumeration of cirumstances; fashioning falsehood by the most rigid standard of probability, and suggesting to the readers beneficial truths, is the sublimest province that can be assigned to man" (quoted in Elliot, 1994: xxvi). Hence when he sent his manuscript of Wieland to Jefferson, he was not only looking for a legitimizing voice that corroborated his literary gift, but he was accomplishing his primary aim -feeding fodder to the politician to make him aware of the realities of the human condition he was ruling. Thus, contrary to Michael D. Bell's opinion, Brown does not seem to have shared the prejudice of his time against fiction writing:

They who prate about the influence of novels to unfit us for solid and useful reading are guilty of a double error: for in the first place, a just and powerful picture of human life in which the connection between vice and misery, and between felicity and virtue, is vividly portrayed, is the most solid and useful reading that a mortal and social being (exclusive of particular cases and professional engagements) can read; and in the second place, the most trivial and trite of these performances are, to readers of certain ages and 
intellects, the only books which they will read... My fancy has received more delight, my heart more humanity, and my understanding more instruction from a few novels I could name, than from any other works (quoted in Elliot, 1994: xxvi).

Fiction becomes in Wieland a way of regeneration as well as a way to expose delusion. According to Elliot, Clara and Carwin "introduce aspects of intellectual scepticism, analogous to what postmodern theorists call indeterminism. The words of Clara and the actions of Carwin suggest the strong possibility that every narrative, every experience, every human judgment is always and necessarily based upon quite uncertain premises and assumptions" (1994: xxii). Clara presents herself to the reader as an unreliable narrator: "My narrative may be invaded by inaccuracy and confusion; but, if I live no longer, I will, at least, live to complete it. What but ambiguities, abruptness, and dark transitions, can be expected from the historian who is, at the same time, the sufferer of these disasters?" (169). But as Elliot thinks, Clara's observation goes beyond her merely personal rendering of her story. What Clara I believe is actually pointing at is the fact that firstly reality is an abstraction impossible to render truthfully, secondly that that rendering is directly dependant on the experience of the renderer, and thirdly that the verbal cast limits that same rendering.

That reality is an abstraction impossible to render truthfully is an idea that cuts across the novel's narrative technique. Reality is duplicitious and through its impenetrable veil nothing can be discerned as appearances are misleading and knowledge to discover it is "sparingly conferred" upon man (119). The key scene in the novel - since it unchains all catastrophic events for the Wieland- is that of Clara in her bedroom and the voices she hears and later, the attack by Carwin. The episode is narrated firstly by Clara, secondly by Pleyel and thirdly by Carwin. Pleyel - a defender of intellectual liberty who rejects all guidance but that of reason - is convinced of the veracity of what he has witnessed by the testimony of his "eyes" and "ears" (121). Clara is bewildered by his accusations as he has drawn the most improbable and unjust conclusions from dubious appearances. What might be labelled as Pleyel's conception of a "virtual reality" leads him into palpable errors, because his imagination has transformed shadows into monsters (157). Pleyel, thus, becomes the most awesome character in the whole novel as he is presented as an example of how even the most rigid champion of rationality can be overthrown by manipulation of evidence, of the senses. In fact, for Carwin, Pleyel "was a man of cold resolves and exquisite sagacity. To deceive him would be the sweetest triumph I had ever enjoyed" (237-238). And what it seems unbelievable for this double-tongued deceiver is that Pleyel was indeed deceived. The question Clara asks continously is in a nutshell -how can we solve a problem of perception? How can we reach at the truth by individual testimony? The question remains answered and is further complicated when Carwin gives a third rendering of the scene of the closet. Hence, the transformation alluded to in the subtitle encloses a triple reference as Pleyel, Wieland and Clara have each been transformed from "rational and human into a creature of nameless and fearful attributes" (205). The problem of how to "unravel the maze" (162) is left unsolved and the perception of reality is distorted and entangled by the passions subsumed in the characters of the performance. 
At first sight, Clara appears to sport a utilitarian view of literature. She tells her tale "to the benefit of mankind" (11), thus serving a purpose of public improvement. But soon after, the reader learns that "it will exemplify the force of early impressions, and show the immeasurable evils that flow from an erroneous or imperfect discipline" (11). Brown unites thus one of the main motifs of the novel - that the rendering of reality is directly dependant on the experience of the renderer- to one of the burning questions of postRevolutionary America -education. Linda Kerber explains that the war of the Revolution and the constitutional experiments that followed composed one of the great ages of political innovation in Western history and in these years the terms were set by which future Americans would understand their relationship to the social order. A restrained, deferential democracy characteristic of American colonial localities gradually gave way to an aggressive, egalitarian, modern participatory democracy. A republican ideology redefined the political order and challenged fundamental assumptions: What does it mean to be a citizen? Who has a right to rule? Who ought to be content with being ruled? (1986: 7). Political theory taught that republics rested on the virtue and intelligence of their citizens. The stability and competence on which republican government relied required a highly literate and politically sophisticated constituency. As Kerber observes "maintaining the Republic was an educational challenge as well as a political one". Consequently, the years immediately after the revolution witnessed a great expansion of educational opportunity, an expansion sustained by the belief that the success of the republican experiment demanded a well-educated citizenry. Listing reading, writing, measurement and arithmetic, geography, and history as the subjects that ought to be taught in primary schools, Thomas Jefferson said the purpose of these institutions was to "instruct the mass of our citizens in these rights, interests and duties, as men and citizens" (1986: 189). However, Jefferson seems to have forgetten an issue fundamental to Brown - how to set a corrective to the nature of $\operatorname{man}^{6}$, since in Wieland its author appears to be less concerned with the formalistic level of education than with the mysteries of the ontology of the citizenry.

On the other hand, the fact that the narrator is a woman cannot just be dismissed as an echo of the sentimental novel narrative technique. Brown in Alcuin: A Dialogue (1798) had composed "America's first book-length text on women's rights" (Elliot, 1994: ix). Inspired by the works of Mary Wollstonecraft, Brown structured his work as a dialogue between a man and a woman who tries to convince the man of the justice of female education and of the need for women's political equality. Consequently, it seems logical that some of his ideas on the role of females in the new Republic seeped into the construction of his first novel and his choice of a woman narrator. Thus, at the beginning of the novel Clara is described as a model republican woman - competent and confident. She resists the vagaries of fashion, is rational, benevolent, independent and self-reliant. As Kerber points out, "the creation of such women in America became a major education challenge. Writers were fond of attributing the inadequacies of American women to early upbringing and environmental influences, a point also raised by English critics like Mary Wollstonecraft". Judith Sargent Murray, Susannah Rowson, and Benjamin Rush developed an ideology for women's education in the Republic, defending improvement in education "without repudiating the relationship of women to their households. These reformers 
avoided challenging directly the old anti-intellectualism that could be counted on to be voiced whenever claims were made for women's intellectual prowess. Instead they contented themselves with deploring the 'dependence for which women are uniformly educated"; they argued that political independence in the nation should be matched by selfreliance on the part of women. The model republican woman was to be self-reliant (within limits), literate, untempted by the frivolities of fashion. She had a responsibility to the political scene, though was not active in it [...] A woman's competence was not assumed to extend to the making of political decisions. Her political task was accomplished within the confines of her family" (1986: 207, 227-228). These ideas and the republican rhetoric that made it convincing appeared fully dramatized in the Columbia College commencement oration of 1795 entitled "Female influence", where the flowery language masks a clear social and political message:

Let us then figure to ourselves the accomplished woman [...] Religion, fairest offspring of the skies, smiles auspicious on her endeavours; the Genius of Liberty hovers triumphant over the glorious scene...Yes, ye fair, the reformation of a world is in your power [...] Reflect on the result of your efforts. Contemplate the rising glory of confederated America. Consider that your exertions can best secure, increase, and perpetuate it. The solidity and stability of the liberties of your country rest with you; since Libery is never sure, 'till Virtue reigns triumphant [...] Already may we see the lovely daughters of Columbia asserting the importance and the honour of their sex. It rests with you to make this retreat [from the corruptions of Europe] doubly peaceful, doubly happy, by banishing from it those crimes and corruptions, which have never yet failed of giving rise to tyranny, or anarchy. While you thus keep our country virtuous, you maintain its independence.

Americans agreed on one point: "in a world where moral influences were fast dissipating, women as a group seemed to represent moral stability" (Kerber, 1986: 230). But, paradoxically, Clara Wieland lacks this quality to such an extent that she has been described by some critics as "suicidal", "fatalistic" with "neurotic tendencies" (Krause and Reid, 1978: xix, xxi). In fact, what Brown does is to retake the figure of the motherless daughter to symbolize America's uncertainty as a nation. If in the contemporary sentimental novels the heroine's plight took on symbolical meaning, in Wieland and through its woman narrator its author retrieves that equation to underscore another tragic dimension to his apocallyptic vision, since the correspondence between domestic felicity and national destiny is closely drawn . Brown adds another brushstroke to the deflation of the American mission as the daughter of Columbia's failure in virtue is made concomitant to the dark being of the nation.

Furthermore, when Clara tells the reader on the first page, "Make what use of the tale you shall think proper" (11), and closes her narrative by saying, "I leave you to moralize on this tale" (275), Brown leaves all responsibility of the moral of the novel on the readers, thus being coherent with his thesis in the work. To the question he has been trying to answer - how can we perceive a truthful picture of reality? - Clara responds by laying all the burden on the morality of actors of her arama and thus, Brown establishes fiction writing beyond the realm of didacticism. It is not just a question of dodgding authorship 
but an overt preoccupation with the nature of writing and literature as doubtful channels of communication and of its immediacy. Similarly to what has happened to "the sufferers", the efficacy of the lesson the reader extracts from the text lies ultimately with the reader's equanimity and foresight.

Finally, Wieland is also a cautionary tale that warns against the superficial image of reality and impinges the reader to look for the first time in American literature for the power of blackness underneath its verbal construct. Wieland was composed in a period when "the Constitution played a key role in the entrenchment of print ideology" (Bercovitch, 1995: 648). Yet not only is the Constitution the political counterpart to Wieland, but the main text against which Brown undermines the possibility of a national identity. If the disruptive elements in the new Republic - the demagogues, for examplecould operate through the impersonal level a generic text offered, the Constitution vested ultimate power in the national government, consequently it reproduced in the political body the essential feature of writing - the nonpresence of the author ${ }^{9}$. Yet, Brown goes a step further in Wieland. Carwin handles "a tool of wonderful efficacy without malignant intentions but without caution" (225) in a world where, as Clara has confessed previously, "how imperfectly acquainted were we with the conditions and designs of the beings that sorrounded us!" (89). Hence, Carwin's ability to speak for others is symbolical of the power of the Republic to voice people's voices. But this power engenders the production of fiction, as Carwin's voices create new stories within the story in Wieland ${ }^{10}$. The point is that the capacity of mimicry is neither good nor pernicious as the evils derived from it will ultimately be placed on "the errors of the sufferers" (275) and on the fictional accounts with which they have attempted to frame reality both national and personal.

On the other hand, there is also in the novel a search of identity amidst the fragmented ruins of Clara's memories. Hence, the inexistence of a voiced moral at the end of the tale is not so much an escape of responsibility on Brown's part, as a strategy that tries to mirror his concern for describing what a virtuous citizen is. Readers are thus thrust into the debatable question and made part of it. Thus, Brown not only makes extravagant claims to disrupt the legitimacy of the narrator's voice, but ultimately reduces her existence to the limits of the text, placing authority outside the very same confines traced by her writing. "When I lay down the pen the taper of life will expire; my existence will terminate with my tale" (250), declares Clara, to repeat soon after: "I will die, but then only when my tale is at an end" (258). Existential identity is equated with appearance in fiction. The Word is transformed into words which become then the bridge that mediates between the citizen individual self-realization and authority and the only viable possibility to transcend the doubtful accuracy of a perceived reality.

As Myra Jehlen points out, Raymond Williams "distinguishes between 'the dominant culture' in the society and certain other 'practices, experiences, meaning, and values' which are 'alternative' to the dominant culture or even 'oppositional' to it; but in America", she adds, "alternative or oppositional forms have characteristically been associated with the Old World and thus rejected by the very process of national emergence" (1986: 127). Brown takes the tale of seduction as remnant of European mores and tries to write an American alternative recurring to the motifs inherent in the Puritan jeremiad, thus the seductive theme is subservient to his aim of showing the elements that compound human 
nature and the new American Republican identity and mission ${ }^{11}$. The American jeremiad, a mode of public exhortation, transfigured in both form and content by the New England Puritans, persisted through the eighteenth century, and helped sustain a national dream through two hundred years of turbulence and change. Perry Miller stressed the dark side of the jeremiad, but Bercovitch thinks this is a partial view of their message, the Puritans's cries of declension and doom were part of a strategy designed to revitalize the errand. Charles Brockden Brown's cries of declension and doom are also part of a strategy to revitalize the errand and, like the jeremiad, they express a profound disquiet, and like it, Wieland can be described as "an affirmation that betrays 'an underlying desperation - $\mathrm{a}$ refusal to confront the present, a fear of the future, an effort to translate 'America' into a vision that works in spirit because it can never be tested in fact"' (Bercovitch, 1978: xiv).

Benjamin Rush, revolutionary physician and patriot, in "An Address to the People of the United States", published in the January 1787 American Museum, expressed what had become for many citizens a commonplace: "There is nothing more common than to confound the terms of the American revolution with those of the late American war. The war is over: but this is far from being the case with the American revolution. On the contrary, nothing but the first act of the great drama is closed. It remains yet to establish and perfect our new forms of government; and to prepare the principles, morals, and manners of our citizens, for these forms of government, after they are established and brought to perfection." Rush concluded by reminding readers that 'THE REVOLUTION IS NOT OVER!' (quoted in Emerson, 1977: 254). Wieland as a jeremiad fashions the myth of America in literary canonical terms. Wieland is not a study in individual dementia, but a profound research in collective flaws, an allegory of the corruption of the republican faith in the virtues of its citizenry, a shocking discovery of inner disorder that mirrors outer turbulence and chaos, a disturbing mindscape of the errand. Brown may be what Leslie A. Fiedler thinks - "a writer careless to the point of shamelessness" (1960: 155), but two hundred years after its composition and near the end of the second millenium, Wieland is still a novel which continues to tap readers' interest in a society marketed as utopian, though lived everyday as delusive.

\section{Notes}

1. Tompkins makes a thorough summary of these critical positions and its supporters in 1985: 207, notes 2 and 3.

2. Charles Brockden Brown,Wieland or, the Transformation: An American Tale (New York: Doubleday, 1989), 7. All further quotations from the novel will refer to this edition and will be cited parenthetically in the text.

3. The American Puritan jeremiad owes its uniqueness to its vision and mode of rhetoric of mission. In Europe, the jeremiad "pertained exclusively to mundane, social matters, to the city of man rather than the city of God. It required not conversion but moral obedience and civic virtue. At best, it held out the prospect of temporal, worldly success. At worst, it threatened not hellfire but secular calamity (disease, destruction, death). The Puritans' concept of errand entailed a fusion of secular and sacred history. The purpose of their jeremiads was to direct an imperiled people of 
God toward the fulfillment of their destiny, to guide them individually toward salvation, and collectively toward the American city of God" (Bercovitch, 1978: 9).

4. Gordon S. Wood describes moral complaint in the decade before the Revolution including these strategies: "[The] prevalence of vice and corruption that many Americans saw in their midst [...] became a stimulus, perhaps in fact the most important stimulus, to revolution [...] The calls for independence thus took on a tone of imperativeness [...] Only this mingling of urgency and anxiety during their introspective probings at the height of the crisis could have given their revolutionary language the frenzied quality it acquired. Only profound doubts could have created their millennial vision of a new society, their idealized expectation that 'on the morrow' there would be a 'new thing under the sun, that hath not been already of old time"' (The Creation of the American Republic, 1776-1789, New York, 1969, 107-8, 404. Cited by Bercovitch, 1978: 121).

5. For a detailed exposition of Brown's theories on the novel, see Perosa, 1983: 3-11.

6. To see about female instruction during the early republic, see Kerber, 1986: chapter 7, "'Why Should Girls be Learnd or Wise?': Education and Intellect in the Early Republic", 185-231.

7. This speech was published as "Female Influence" in New York Magazine (May 1795), 301305. Cited by Kerber 1986: 230.

8. For a study of how sentimental fiction written by women was primarily instructive to the young nation and the role of women in relation to the political building of the Republic, see article by Davidson.

9. This idea is taken from Bercovitch, 1995: 648-649.

10. For Fliegelman, "Brown's novel of authority misrepresented and authority imagined is a terrifying post-French Revolutionary account of the fallibility of the human mind and, by extension, of democracy itself" (1995: x-xi).

11. Larzer Ziff states that Brown turns against the sentimental novel and uses its expectations "to show that life is far more complicated than his novels tell him that it is" (1962: 52).

\section{Works Cited}

Bain, Robert (1977): “The Federalist". In Everett Emerson, ed., American Literature, 1764-1789. The Revolutionary Years. Madison, Wisconsin: University of Wisconsin Press, 253-273.

Baym, Nina (1987): Novels, Readers and Reviewers: Responses to Fiction in Antebellum America. Ithaca and London: Cornell University Press.

Bell, Michael D. (1980): "'The Double-Tongued Deceiver': Sincerity and Duplicity in the Novels of Charles Brockden Brown". In Michael T. Gilmore, ed., Early American Literature: A

Collection of Critical Essays. Englewood Cliffs, N.J.: Prentice-Hall, Inc., 133-157.

Bercovitch, Sacvan (1978): The American Jeremiad. Madison, Wisconsin: University of Wisconsin Press. . ed (1995): "Charles Brockden Brown". The Cambridge History of American Literature.

Vol. I 1590-1820. New York: Cambridge University Press, 644-660.

Brown, Charles Brockden (1989): Wieland or, the Transformation: An American Tale. 1798. New York: Anchor Books, Doubleday.

Chase, Richard (1957): The American Novel and Its Tradition. Garden City, New York: Anchor Books. 
Davidson, Cathy N. (1980): "Mothers and Daughters in the Fiction of the New Republic". In Cathy N. Davidson and E. M. Broner, eds., The Lost Tradition: Mothers and Daughters in Literature. New York: Frederick Ungar Publishing Co., 115-127.

Emerson, Everett, ed. (1977): American Literature, 1764-1789: The Revolutionary Years. Madison, Wisconsin: University of Wisconsin Press.

Elliot, Emory (1994): "Introduction". Wieland or, the Transformation: An American Tale. By Charles Brockden Brown. New York: Oxford University Press, vii-xxx.

Fiedler, Leslie A. (1960): Love and Death in the American Novel. Penguin: Harmondsworth.

Fliegelman, Jay (1995): "Introduction". Wieland or, the Transformation: An American Tale. By Charles Brockden Brown. New York: Penguin Classics.

Jehlen, Myra (1986): "The Novel and the Middle Class in America". In Sacvan Bercovitch and Myra Jehlen, eds, Ideology and Classic American Literature. New York: Cambridge University Press, 125-144.

Kerber, Linda K. (1986): Women of the Republic: Intellect and Ideology in Revolutionary America. New York \& London: W. W. Norton \& Company.

Krause, Sydney J. and S. W. Reid (1978): "Introduction". Wieland or, the Transformation: An American Tale. By Charles Brockden Brown. Kent, Ohio: Kent State University Press, vii$\mathrm{xxv}$.

Mulford, Carla (1996): "Introduction". The Power of Sympathy by William H. Brown and The Coquette by Hannah W. Foster. New York: Penguin Books, ix-li.

Pattee, Fred Lewis (1926): "Introduction". Wieland or, the Transformation: An American Tale. By Charles Brockden Brown. New York: Harcourt Brace Jovanovich, ix-xlvi.

Perosa, Sergio (1983): American Theories of the Novel: 1793-1903. New York: New York University Press.

Seelye, John (1991): "Brown and Early American Fiction". In Emory Elliot, gen. ed., The Columbia History of the American Novel. New York: Columbia University Press, 168-186.

Tompkins, Jane (1985): "What happens in Wieland". Sensational Designs: The Cultural Work of American Fiction, 1790-1860. New York: Oxford University Press, 40-61.

Ziff, Larzer (1962): “A Reading of Wieland". PMLA 77: 51-57. 